\title{
Influence of tail biting on weight gain, lesions and condemnations at slaughter of finishing pigs ${ }^{1}$
}

\author{
Brenda Maria F.P.P. Marques², Mari L. Bernardi ${ }^{3}$, Carolini F. Coelho ${ }^{2}$, Mirian Almeida ${ }^{2}$, \\ Oscar E. Morales ${ }^{2}$, Tiago J. Mores ${ }^{2}$, Sandra M. Borowski ${ }^{4}$ and David E.S.N. Barcellos ${ }^{2 *}$
}

\begin{abstract}
Marques B.M.F.P.P., Bernardi M.L., Coelho C.F., Almeida M., Morales O.E., Mores T.J., Borowski S.M. \& Barcellos D.E.S.N. 2012. Influence of tail biting on weight gain, lesions and condemnations at slaughter of finishing pigs. Pesquisa Veterinária Brasileira 32(10):967-974. Setor de Suínos, Faculdade de Veterinária, Universidade Federal do Rio Grande do Sul, Avenida Bento Gonçalves 9090, Porto Alegre, RS 91540-000, Brazil. E-mail: davidbarcellos@terra.com.br

The present study assessed the association of tail-biting lesions in finishing pigs with weight gain, occurrence of locomotion or respiratory disorders and abscesses during finishing period, and carcass condemnation at slaughter. The study was carried out on 4 different farms. For each animal with a tail biting lesion, two control pigs were selected. The total number of animals in the study was 312, with 104 of them being tail-bitten. Tail lesions were classified according to the degree of severity into four scores: score 0 -normal tail withou lesion; score 1-3 - increasing lesion severity, and score 4 - healed lesions. Overall, the occurrence of severe tail lesions (score 3) varied from 55 to $73 \%$ of tail-bitten pigs among farms. On all farms, healing of tail lesions was observed in $95 \%$ to $100 \%$ of the animals at the evaluation performed within 41-43 days after the commencement of the study. In two out of the four evaluated farms, pigs with score of 3 showed lower weight gain $(\mathrm{P}<0.05)$ compared with score 0 pigs. Before slaughter, the occurrence of locomotion problems and nodules/abscesses was associated $(\mathrm{P}<0.05)$ with the presence of tail-biting lesions. At slaughter, tail-biting lesions were associated $(\mathrm{P}<0.05)$ with the presence of abscesses, lung lesions (pleuritis and embolic pneumonia) or arthritis in carcasses. Carcass condemnation was associated with the presence of tail-biting lesions $(\mathrm{P}<0.05)$. Overall, carcass condemnation rate was $21.4 \%$, of which animals with tail-biting lesions accounted for $66.7 \%$ of condemnations. Among the animals diagnosed with cannibalism at farm level, only two had not healed their lesions at slaughter. The fact that there were a lot of carcass condemnations, despite the fact that tail-bitten animals had no more active lesions, suggests that different situations may be observed between the field and slaughter, reinforcing the need to analyze pigs both at farm and slaughter to allow proper assessment of losses related to tail biting. Collectively, the observations of the present study show that complications associated with tail-biting found in slaughterhouses are probably underestimating field prevalence.
\end{abstract}

INDEX TERMS: Swine, tail biting, cannibalism, animal health, condemnations, pleuritis, abscesses.

\footnotetext{
${ }^{1}$ Received on December 13, 2011.

Accepted for publication on June 14, 2012.

${ }^{2}$ Setor de Suínos da Faculdade de Veterinária, Universidade Federal do Rio Grande do Sul (UFRGS), Av. Bento Gonçalves 9090, Porto Alegre, RS 91540-000, Brazil. Corresponding author: davidbarcellos@terra.com.br

${ }^{3}$ Departamento de Zootecnia, Faculdade de Agronomia, UFRGS, Av. Bento Gonçalves 7712, Porto Alegre, RS.

${ }^{4}$ Laboratório de Patologia Suína, Centro de Pesquisa Veterinária Desidério Finamor (IPVDF), Cx. Postal 47, Eldorado do Sul, RS 92990-000, Brazil.
}

RESUMO.- [Influência do canibalismo de cauda no ganho de peso, lesões e condenações ao bate de suínos em terminação.] 0 presente estudo avaliou a associação das lesões de canibalismo de cauda em suínos de terminação com o ganho de peso, ocorrência de problemas locomotores ou respiratórios e abscessos durante a fase de terminação, e condenação de carcaças ao abate. 0 estudo foi realizado em quatro granjas comerciais de suínos. Para 
cada animal com lesão de canibalismo de cauda, outros dois suínos na mesma baia foram selecionados como controle, totalizando 312 animais avaliados. As lesões de cauda foram classificadas de acordo com o grau de severidade em quatro escores: score 0 - cauda normal, sem lesão; escores de 1 a 3 - de acordo com o aumento da severidade da lesão, e escore 4 - lesões cicatrizadas. No total, suínos com lesões severas (escore 3) corresponderam a 55-73\% dos animais com lesão de caudofagia. Em todas as granjas, a cicatrização das lesões de cauda foi observada em $95 \%$ a $100 \%$ dos animais na avaliação realizada entre 41-43 dias após o início do estudo. Animais com escore 3 apresentaram menor ganho de peso $(\mathrm{P}<0,05)$ quando comparados com animais de escore 0 , em duas das quatro granjas avaliadas. Antes do abate, a ocorrência de problemas locomotores e de nódulos/abscessos foi associada $(\mathrm{P}<0,05) \mathrm{com}$ a presença de lesões de caudofagia. Ao abate, as lesões de canibalismo de cauda foram associadas $(\mathrm{P}<0,05) \mathrm{com}$ a presença de abscessos, lesões pulmonares (pleurite e pneumonia embólica) ou artrite na carcaça. A condenação de carcaça foi associada com a presença de lesões de canibalismo de cauda $(\mathrm{P}<0,05)$. A taxa de condenação de carcaças foi de $21,4 \%$, sendo que os animais com lesões de canibalismo de cauda corresponderam a $66,7 \%$ dessas condenações. Dos animais diagnosticados com canibalismo de cauda, somente dois apresentavam lesões ativas ao abate. 0 aumento do número de condenações no abate nos lotes estudados sugere que diferentes situações sanitárias podem ser observadas a campo e ao abate, reforçando a necessidade de analisar os animais na granja e ao abate, a fim de permitir uma avaliação precisa das perdas associadas ao canibalismo de cauda. Coletivamente, as observações do presente estudo sugerem que as complicações associadas com o canibalismo da cauda verificadas no abate provavelmente representam uma subestimativa da prevalência encontrada nas granjas.

TERMOS DE INDEXAÇÃO: Canibalismo de cauda, escore, condenações, pleurite, abscessos.

\section{INTRODUCTION}

Tail biting is among the most frequent abnormal behaviors in swine, although its causes are not well determined. In addition to the negative impact on animal welfare (Breuer et al. 2005), the association of tail biting with secondary infections and body condition loss may result in substantial economic losses (Kritas \& Morrison 2007).

In the study of Wallgren \& Lindahl (1996), tail biting significantly impaired animal growth not only during the period of active tail lesions, but also in later periods, extending up to slaughter age. In slaughterhouses, abscesses, lung lesions, and carcass condemnations may be associated with tail biting or cannibalism (Kritas \& Morrison 2007). In Ireland, Huey (1996) showed that tail biting was the cause of infections present in $19.9 \%$ of carcasses with one single abscess and in $61.7 \%$ of carcasses with more than one abscess. In Brazil, out of the 34,194 carcasses condemned by the Federal Inspection Service (SIF), 727 (2.1\%) were due to tail biting (Braga et al. 2006).
Information on tail biting is mostly found in studies on risk factors and slaughterhouse reports (Moinard et al. 2003, Kritas \& Morrison 2007). Data on cannibalism, considering only slaughter data - not taking into account how the problem occurred in the field - may be rather imprecise because pigs whose lesions heal before slaughter may be incorrectly considered as not being previously bitten. Data on the evolution of the disease in affected groups, measuring impacts on weight gain and mortality in the field, as well as on quality of the carcass, are also lacking.

The objective of the present study was to evaluate the association of tail biting with health status and live performance of finishing pigs. Furthermore, these pigs were followed through to slaughter, regardless the evolution of tail lesions, to verify the impact on lesions and condemnations at slaughter.

\section{MATERIALS AND METHODS}

\section{Local and facilities}

Four finishing units located in the region of Vale do Taquari, state of Rio Grande do Sul, Brazil, with active cases of tail biting were included in the study. Before starting the study, it was decided that the herds to be evaluated should belong to the same company and that farmers should inform the researchers when they had at least 10 affected pigs to be followed. Finishing farms followed the same general management and cleaning routines, and food was produced in the same feed mill. Considering feed management, building and pen design, environmental control and size of herds, the visited farms are typical of the production system of the three southernmost states of Brazil, which account for about $50 \%$ of the Brazilian pig production.

All the farms had an all in-all out management system and facilities were submitted to natural ventilation through manual operation of curtains. On each farm, all the pigs originated from one herd and animals were managed according to the company standards. The pens had solid concrete floor, of which one third was slatted in the rear end, and were mechanically cleaned twice a day. No bedding material was provided, but 1-2 hang chains per pen were provided as environmental enrichment to the animals. Stocking density ranged from 17 to 30 pigs/pen and the space allowance varied on average from 0.9 to $1.0 \mathrm{~m}^{2}$ per housed pig. Pelleted feed was manually offered three times a day. Feeder space varied from 23 to $30 \mathrm{~cm}$ per pig. Barrows were studied on FARM1, gilts on FARM2 and FARM3, whereas barrows and gilts were evaluated on FARM4.

During the experiment, routine farm management and/or applied treatments on each farm were not changed. The recommendation of the Company was to treat animals with more severe lesions. As farm personnel did not known in advance the score pigs would receive, in some cases pigs moderate lesions were also treated as it was the case for $50 \%$ of pigs with score 2, on FARM 4. For severe tail biting cases and locomotion disorders, the treatment consisted of Ampicillin $(10 \mathrm{mg} / \mathrm{kg})$ and Dexamethasone $(0.025 \mathrm{mg} / \mathrm{kg})$ for $3-5$ days. Unguent spray was applied in all tail-bitten pigs. Respiratory disorders were treated with Ceftiofur (1$3 \mathrm{mg} / \mathrm{kg}$ ) for 3 days, and diarrhea with Enrofloxacin $(2.5 \mathrm{mg} / \mathrm{kg})$ or Tiamulin $(10-15 \mathrm{mg} / \mathrm{kg}$ ) for3-5 days. Age and weight of pigs at the start and end of the study are shown in Table 1. All pigs that died during the experimental period were recorded and, whenever possible, submitted to necropsy by researchers.

Visits to farms were performed by a team of researchers. It was ensured to always have the same person coordinating the activities, collect data and perform clinical examinations. 
Table 1. Age, weight and number of affected pigs in a tail biting study on four Brazilian farms

\begin{tabular}{|c|c|c|c|c|c|c|c|c|}
\hline & \multicolumn{2}{|c|}{ Farm 1} & \multicolumn{2}{|c|}{ Farm 2} & \multicolumn{2}{|c|}{ Farm 3} & \multicolumn{2}{|c|}{ Farm 4} \\
\hline & CONT & CAN & CONT & CAN & CONT & CAN & CONT & CAN \\
\hline № of pigs in the herd & 330 & & 380 & & 400 & & 635 & \\
\hline Historical data on tail biting & yes & & no & & no & & yes & \\
\hline № of pigs in the study & 58 & 29 & 22 & 11 & 40 & 20 & 88 & 44 \\
\hline Starting age of pigs & $94.8 \pm 1.6$ & $93.9 \pm 2.5$ & $94.2 \pm 2.2$ & $95.4 \pm 3.3$ & $81.5 \pm 2.3$ & $80.3 \pm 3.6$ & $75.6 \pm 1.1$ & $76.0 \pm 1.5$ \\
\hline Initial weight, kg & $49.8 \pm 0.9$ & $49.4 \pm 1.3$ & $44.7 \pm 1.1$ & $45.3 \pm 1.6$ & $32.2 \pm 0.9$ & $31.8 \pm 1.4$ & $31.6 \pm 0.4$ & $31.8 \pm 0.6$ \\
\hline Pigs treated - tail lesion* & - & 16 & - & 8 & - & 11 & - & 31 \\
\hline Pigs treated - other reasons ${ }^{* *}$ & 0 & 7 & 1 & 2 & 0 & 5 & 4 & 15 \\
\hline
\end{tabular}

$\mathrm{a}$ and $\mathrm{b}$ : indicate significant difference between Control (CONT) and tail-bitten pigs (CAN), within each farm $(\mathrm{P}<0.05) .{ }^{*}$ Numbers of treated pigs correspond to those with severe lesion (score 3) in Farms 1, 2 and 3; in Farm 4, in addition to those with severe lesions, 50\% of pigs with moderate lesion (score 2) were also treated with Ampicillin $(10 \mathrm{mg} / \mathrm{kg})$ and Dexamethasone $(0.025 \mathrm{mg} / \mathrm{kg})$ for $3-5$ days. ${ }^{* *}$ Other reasons included locomotion problems, respiratory disorders, diarrhea and meningitis.

\section{Animals and evaluations}

Pigs included in the study had similar genetics (PIC®) Camborough 25), and had been submitted to routine docking of two-thirds of the tail when they were 3 days of age. For each animal which was tail-bitten (cannibalism - CAN), two control pigs (CONT), having similar weight, sex, age and origin, were selected; this established a trio of pigs. Two control pigs were used because control animals could be bitten during the experimental period and they should, therefore, not be considered as control ones. Control pigs were randomly chosen among animals of pens in each side of a central aisle. CAN and CONT pigs were identified with different colored tags and housed in the original pens, excepting those severely affected which were transferred to hospital pens to enhance their welfare and prevent them being bitten again. After the trios had been established, new cases of cannibalism were not taken into account for the analyses. During the evaluation period, nine animals of the CONT group acquired tail-biting lesions. The decision was to exclude from the statistical analysis those trios containing control pigs which were bitten. Numbers of pigs belon- ging to CONT and CAN groups that were maintained in the analysis are presented in Table 1.

The study was divided in two stages: the first was carried out on the farm, and the second at a slaughterhouse. During the first stage, the following activities were carried out:

a) Live performance evaluation: Depending on the age of the animals when cannibalism was diagnosed they had their weight assessed 4 times on FARM1, FARM2 and 5 times on FARM3 and FARM4. Intervals between the first weight measurements were of 19-21 days and the last interval was of 29-33 days.

b) Lesion scoring: during each visit, tails were visually examined (always by the same evaluator) and scored according to a scale of tail lesions (Fig.1). Only animals with active lesions, i.e., with scores 1 to 3 were included in the CAN group.

c) Other evaluations: each time pigs were weighed they were clinically examined for locomotion and respiratory disorders as well as for the presence of nodules and/or abscesses on the tail and posterior region of the body. Locomotion problems were recognized when lameness, hoof lesions and joint swelling were
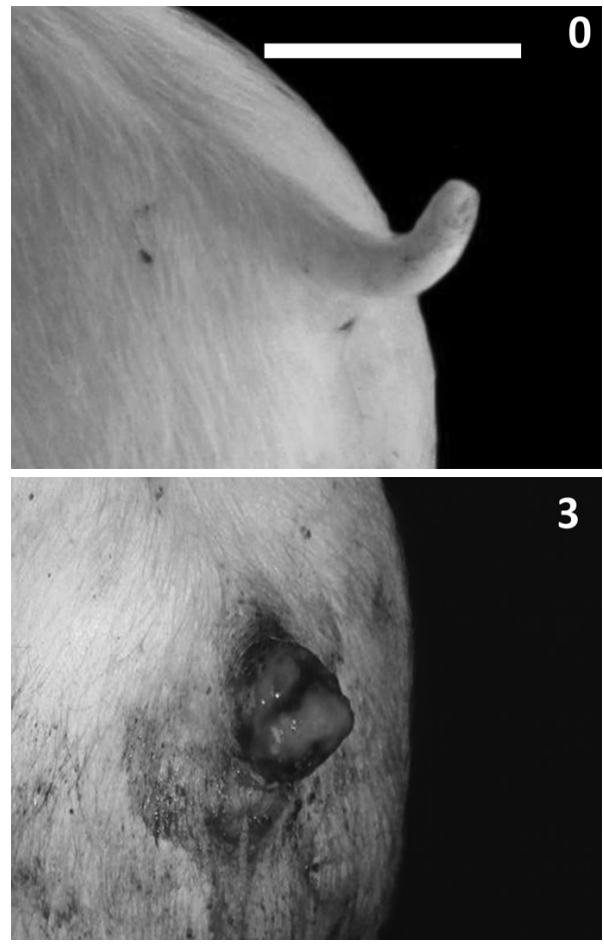
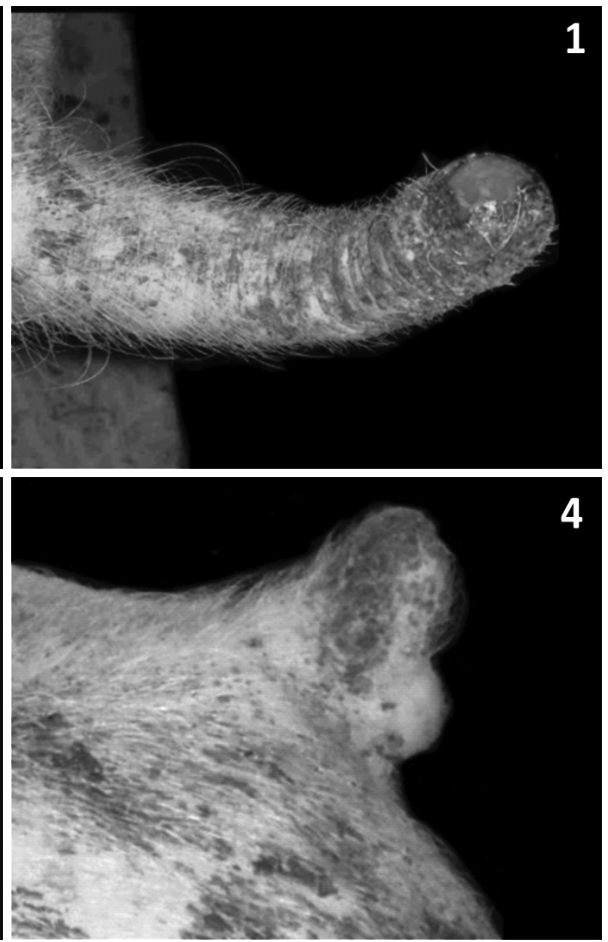

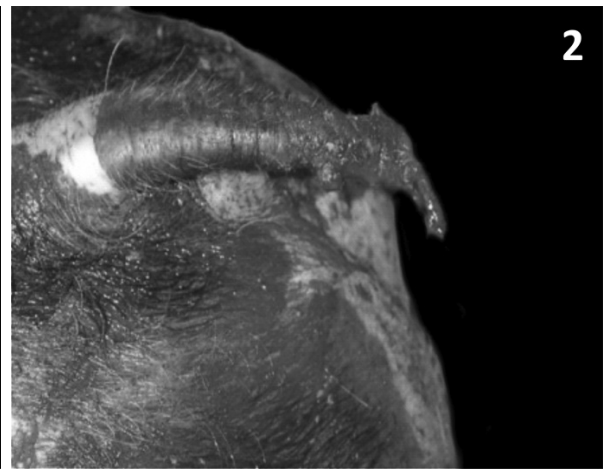

4

Fig.1. Scoring system for tail biting lesions. Score 0 - Without lesion, normal tail; Score 1 - Discrete lesion, with superficial loss of epithelial tissue; Score 2 - Moderate lesion, with up to $50 \%$ of the tail injured or lost; Score 3 - Severe lesion, more than $50 \%$ of the tail injured or total loss of the tail; Score 4 - Healed lesion. 
present. Affected animals were submitted to further analyses as described by Schulze (1980). This examination consisted of inspection of standing and moving animals, followed by visual examination and palpation. Respiratory problems were diagnosed by the analysis of cough, sneezing and dyspnea, according to Sobestiansky \& Barcellos (2007).

During the second stage of this study, the slaughter of the experimental animals was followed up. Animals of all farms were slaughtered in the same slaughterhouse and within each farm both CONT and CAN pigs were slaughtered at the same age. At the abattoir, animals were submitted to a slaughter check using methods and criteria generally used in Brazilian slaughterhouses (Sobestiansky et al. 2007). The age at slaughter is presented in Table 1. One person registered the tag number and the sequence of entrance in the processing line, while another person identified the offal with the corresponding slaughter number in the offal line. At the offal line, lungs were placed in plastic bags for further analysis of lung lesion type and extension (pneumonia, abscesses, and pleuritis). Cases of arthritis were detected by inspection and opening of the joints. Positive cases were defined considering alterations of joint fluid, capsule and joint cartilage.

Pigs that had their carcasses condemned as well as lesions on the carcass (e.g., pleuritis, abscesses, or other lesions) were recorded. According to the final meat utilization (SIF criteria), non-exportable destination, sausage and preserve corresponded to partial carcass condemnation whereas rendering resulted in a whole carcass condemnation.

In lungs and carcasses with abscesses, fragments of tissues were aseptically collected in the transition zone between the affected and normal areas and submitted for bacteriological examination. Samples were refrigerated between 4 to $8^{\circ} \mathrm{C}$, and processed not later than $96 \mathrm{~h}$ after collection. Routine techniques were used in the bacteriological tests as described by Barrow \& Feltham (1999).

\section{Statistical analysis}

All statistical analyses were carried out using the program Statistical Analysis System, version 9.1.3 (SAS 2005) and a significance level of $5 \%$ was used for comparisons. The frequency distribution of pigs in the CAN group, according to the score of tail lesion, was obtained using the FREQ procedure. Within each farm, percentages of pigs with healed lesions (score 4) were compared, among evaluations, with Chi-square or Fisher's exact test. The mortality rate was analyzed with the Fisher's Exact Test.

Average daily weight gain (ADWG) was analyzed as a repeated measure with the MIXED procedure, including fixed effects of farm, score of tail lesion, moment of weighing and interaction among these factors. Means were compared by the Tukey-Kramer test at a 5\% significance level.

The possible association of tail biting observed during the fattening period, with the occurrence of lesions before slaughter was analyzed with logistic regression models (LOGISTIC procedure). Only new cases of nodules/abscesses, locomotion and respiratory disorders observed during the period of evaluation were taken into account to perform the comparison among the scores of tail biting lesion. The results of several evaluations were combined and the occurrence of new cases was considered as positive when the lesion was detected in at least one of the examinations performed. Because in Farm 2 there were no new cases of lesions, it was not included in this analysis. The possible association of tail lesion scores with the presence of lesions at slaughter, as well as with carcass condemnation (partial or whole), was analyzed using logistic regression models (LOGISTIC procedure), including the effect of farms and of tail lesion scores. However, models for arthritis after slaughter and total carcass condemnation were run without the inclusion of data concerning Farm 2 because these events were not observed in this farm. When slaughter data were analyzed, ten pigs that lost their identification tag and eight pigs that died on the farm were excluded, remaining a total of 294 pigs, being 93 from the CAN group and 201 from the CONT group.

\section{RESULTS}

During the observation period, three out of four farms did not show any particular or significant number of cases of the main diseases that usually affect pigs in this stage of growth in farms from southern Brazil (diarrhea, pneumonia, PCV2 infection and streptococcal meningitis). Mild forms of diarrhea were present, affecting 1 to 3 animals in no more $5 \%$ of the pens. Coughing and sneezing were respectively below $10 \%$ and $15 \%$, using sneeze and cough counts (Sobestiansky \& Barcellos 2007). Using this system of monitoring, the classification obtained was "good health". All herds were vaccinated against PCV2 infection and no significant symptoms of this disease were observed. The fourth herd (Farm 3) presented a similar status regarding diseases described above, but presented an active problem of streptococcal meningitis with 8 deaths among 400 animals (2.0\%). At the abbatoir, the evaluated herds were classified with pneumonia present, but not representing a significant threat.

The prevalence of tail biting on each farm and average tail size of CONT and CAN pigs are showed in Table 1. In Figure 2 is shown the evolution of tail-biting score in CAN pigs during the four evaluations performed. In all farms, healing of tail biting lesions (score 4) was observed in 95 to $100 \%$ of the animals at the third evaluation. Among pigs with cannibalism lesions, only two had not healed lesions at slaughter.

There was a significant effect $(\mathrm{P}<0.05)$ of the interaction between farm and score of tail lesion on ADWG (Table 2). A lower ADWG was observed in pigs with more severe tail biting lesions (score 3) compared to pigs without tail lesions (score 0), on FARM1 and FARM3 but not on FARM2 and FARM4.

New cases of respiratory disorders, abscesses and locomotion problems were observed only in FARM1, Farm 3 and Farm 4. At the beginning of the study, these problems were not present in pigs of CONT group whereas in the CAN group there were 1, 1 and 4 pigs with respiratory disorders, abscesses and locomotion problems, respectively. The effect of farm was not significant $(\mathrm{P}>0.05)$ in the model used to investigate the association of tail biting and the occurrence of new cases of clinical problems. Pigs with score 3 had higher odds of presenting locomotion disorders than CONT pigs and both score 1-2 and score 3 pigs had higher odds of having nodules/abscesses than CONT pigs $(\mathrm{P}<0.05$; Table 3$)$. There was no association $(\mathrm{P}>0.05)$ of tail lesion scores with the occurrence of respiratory disorders.

Posterior paresis or other severe locomotion problems were diagnosed in 10 animals of the CAN group, and no cases in the CONT group. Respecting the principles of animal welfare, these severely affected animals were transferred to hospital pens and, among them, 4 recovered, 3 became permanently lame and 3 were euthanized for humane rea- 

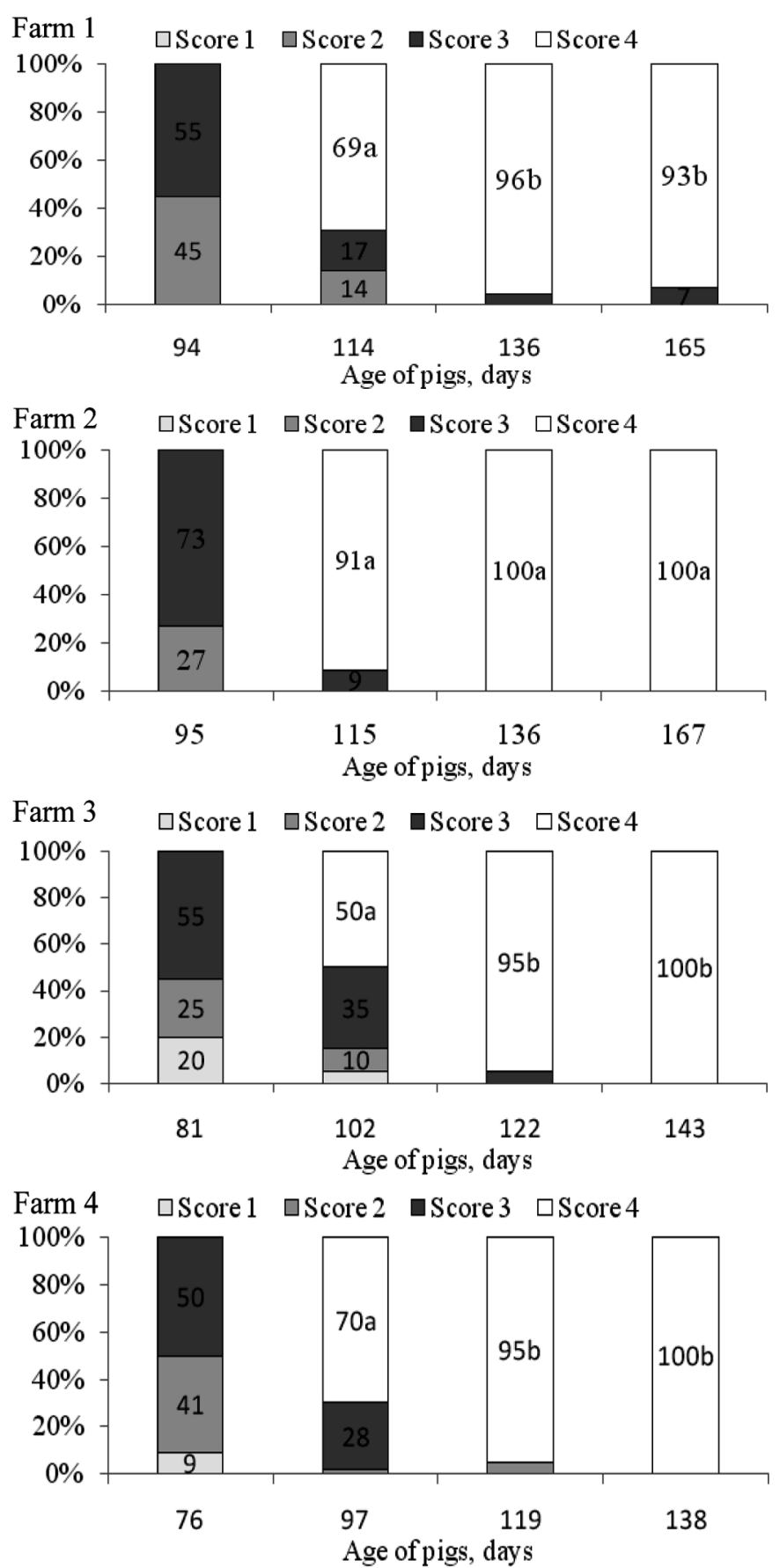

Fig.2. Percentage of animals affected according to the score of tail-biting lesion at each evaluation. Score of lesions: 1 . light lesion, with superficial loss of epithelium; 2 . moderate lesion with up to $50 \%$ of the tail injured or lost; 3 . severe lesion, with more than $50 \%$ of injured tail or total loss of the tail, and 4. healed lesion. Within each farm, the percentages of pigs with healed lesions (score $=4$ ) were compared among the three evaluations performed after starting the study, and values followed by different letters are statistically different $(\mathrm{P}<0.05)$.

son because they presented severe and irreversible lesions. The post mortem examination of these 3 pigs revealed severe arthritis and multifocal abscesses on the posterior region. One pig also presented lung abscesses (embolic pneumonia), and another had abscesses localized in the region of the thoracic vertebral column. Taking into account 5 dead pigs and 3 euthanized, the mortality rate in the CAN
(5.8\%; 6/104) group was higher $(\mathrm{P}<0.05)$ than that of the CONT $(1.0 \% ; 2 / 208)$ group.

Embolic pneumonia (4 pigs) and pleuritis (26 pigs) were grouped and considered as lung lesions. The effect of farm was not significant $(\mathrm{P}>0.05)$ and the occurrence of abscesses, arthritis or lung lesions was associated with the score of tail lesion $(\mathrm{P}<0.05$; Table 3$)$.

Table 2. Average daily weight gain $(\mathrm{kg})$ according to the initial score of tail lesion during the fattening of pigs in 4 Brazilian farms (LSmeans \pm SEM)

\begin{tabular}{cccc}
\hline \multirow{2}{*}{ Farm } & \multicolumn{3}{c}{ Score of tail lesion } \\
\cline { 2 - 4 } & 0 & $1-2$ & 3 \\
\hline FARM1 & $1.05 \pm 0.02 \mathrm{a}$ & $1.01 \pm 0.04 \mathrm{ab}$ & $0.96 \pm 0.03 \mathrm{~b}$ \\
FARM2 & $1.02 \pm 0.03$ & $0.98 \pm 0.08$ & $1.07 \pm 0.05$ \\
FARM3 & $1.08 \pm 0.02 \mathrm{a}$ & $1.13 \pm 0.04 \mathrm{a}$ & $0.97 \pm 0.04 \mathrm{~b}$ \\
FARM4 & $0.86 \pm 0.01$ & $0.92 \pm 0.03$ & $0.86 \pm 0.03$
\end{tabular}

LSmeans + SEM = Least Square Means + Standard Error of Mean. Score of tail lesions. 0 = without lesion, normal tail; 1 = light lesion, with superficial loss of epithelium; 2 = moderate lesion with up to $50 \%$ of the tail injured; 3 = severe lesion, with more than $50 \%$ of the tail injured or total loss of the tail; $a$ and $b$ in the same row indicate significant difference $(\mathrm{P}<0.05)$ among scores of tail lesion.

Table 3. Lesions observed before and after slaughter according to the initial score of tail lesion during the fattening of pigs in 4 Brazilian farms

\begin{tabular}{|c|c|c|c|c|c|}
\hline Lesions & $\begin{array}{c}\text { Score of } \\
\text { tail lesion* }\end{array}$ & $\begin{array}{l}\text { Pigs with } \\
\text { lesions (\%) }\end{array}$ & $\begin{array}{l}\text { Odds } \\
\text { ratio }\end{array}$ & $\begin{array}{l}\text { Confidence } \\
\text { Interval }\end{array}$ & P-value \\
\hline Before slaughter ${ }^{*}$ & & & & & \\
\hline Locomotor disorders & $0(n=186)$ & $3(1.6)$ & 1.0 & - & - \\
\hline & $1-2(n=44)$ & $1(2.3)$ & 1.4 & $0.07-11.4$ & 0.765 \\
\hline & $3(n=49)$ & $12(24.5)$ & 19.8 & $5.9-90.0$ & $<0.0001$ \\
\hline Nodule and/or & $0(n=186)$ & $2(1.1)$ & 1.0 & - & - \\
\hline abscesses & $1-2(n=44)$ & $4(9.1)$ & 9.2 & $1.7-68.0$ & 0.012 \\
\hline & $3(\mathrm{n}=49)$ & $11(22.4)$ & 26.6 & $6.8-176.7$ & $<0.0001$ \\
\hline Respiratory disorders & $0(n=186)$ & $6(3$. & 1.0 & - & - \\
\hline & $1-2(n=44)$ & $1(2$ & 0.7 & $0.03-4.1$ & 0.721 \\
\hline & $3(n=4$ & $4(8.2)$ & 2.8 & $0.7-10.3$ & 0.128 \\
\hline After & & & & & \\
\hline Abscesses & $0(\mathrm{n}=$ & & 1.0 & - & - \\
\hline & $1-2(\mathrm{n}$ & $9(2)-1) \cdot x$ & 18.6 & $5.2-87.1$ & $<0.0001$ \\
\hline & $3(n=52)$ & $17(32.7)$ & 32.1 & $10.1-142.5$ & $<0.0001$ \\
\hline Lung lesions $^{* * *}$ & $0(\mathrm{n}=201)$ & $7(3.5)$ & 1.0 & - & - \\
\hline & $1-2(n=41)$ & $8(19$. & 6.7 & $2.3-20.4$ & 0.0005 \\
\hline & $3(\mathrm{n}=52)$ & $15(28.8)$ & 11.2 & $4.4-31.2$ & $<0.0001$ \\
\hline Arthritis $^{+}$ & $0(n=179)$ & $1(0.6)$ & 1.0 & - & - \\
\hline & $3(\mathrm{n}=44)$ & $4(9.1)$ & 17.8 & $2.5-353.0$ & 0.011 \\
\hline Other lesions ${ }^{++}$ & $0(\mathrm{n}=201)$ & $25(12.4)$ & 1.0 & - & - \\
\hline & $1-2(n=41)$ & $6(14.6)$ & 1.2 & $0.5-3.2$ & 0.70 \\
\hline & $3(n=52)$ & $12(23.1)$ & 2.1 & $1.0-4.6$ & 0.06 \\
\hline
\end{tabular}

*Score of tail lesions. $0=$ without lesion, normal tail; $1=$ light lesion, with superficial loss of epithelium; 2 = moderate lesion with up to $50 \%$ of the tail injured; 3 = severe lesion, with more than $50 \%$ of the tail injured or total loss of the tail.

+ Corresponds to new cases of lesions observed in Farms 1, 3 and 4; data concerning Farm 2 are not included in this analysis because new lesions were not observed during the period evaluated.

${ }^{* *}$ Ten pigs that lost their identification tag and eight pigs that died in the farms are not included in these analyses.

${ }^{* * *}$ Lung lesions refer to pleuritis and embolic pneumonia.

+ In order to estimate the maximum likelihood and the model to be valid, data concerning pigs of Farm 2 and data of pigs with scores 1 and 2 were not included in the analysis because in these cases arthritis was not observed.

${ }^{++}$Other lesions included mesenteric lymphadenitis and pericarditis. 
The effect of farm was not significant $(P>0.05)$ in the model used to investigate the association of tail lesion score and carcass condemnation. Animals with lesions of scores 1-2 and 3 had higher odds of having their carcasses condemned as compared to animals without tail lesions (Table 4). Overall, $21.4 \%$ (63/294) of the carcasses were condemned being $19 \%$ of partial and $2.4 \%$ of whole condemnation. Pigs of the CAN group accounted for $66.7 \%(42 / 63)$ of the condemnations.

Abscesses were diagnosed in 32 carcasses (29 slaughtered and 3 necropsies), with 17 located in the vertebral colu$\mathrm{mn}$, seven in subcutaneous inguinal area, five in lungs, four in the superficial lateral region of the carcass and two in the tail. In three animals of the CAN group, abscesses were found simultaneously in two areas, one animal with abscesses in the vertebral column and in the lungs, and the other two had abscesses in the tail and the inguinal area. The bacteriological examination of 23 sampled abscesses samples showed that ten (43.5\%) were positive for Streptococcus spp., three (13\%) for both Streptococcus spp. and Arcanobacterium spp., two (8.7\%) for Arcanobacterium spp., two (8.7\%) for Pasteurella multocida capsular type A, five $(21.7 \%)$ presented mixed bacterial flora, and one $(4.3 \%)$ was negative.

Table 4. Carcass condemnation according to the initial score of tail lesion during the fattening of pigs in 4 Brazilian farms

\begin{tabular}{cccccc}
\hline $\begin{array}{c}\text { Carcass } \\
\text { condemnation }\end{array}$ & $\begin{array}{c}\text { Score of tail } \\
\text { lesion* }\end{array}$ & $\begin{array}{c}\text { Condemned } \\
(\%)\end{array}$ & $\begin{array}{c}\text { Odds } \\
\text { ratio }\end{array}$ & $\begin{array}{c}\text { Confidence } \\
\text { Interval }\end{array}$ & P-value \\
\hline Partial + total $^{* *}$ & $0(\mathrm{n}=201)$ & $21(10.4)$ & 1.0 & - & - \\
& $1-2(\mathrm{n}=41)$ & $15(36.6)$ & 4.9 & $2.2-10.8$ & $<0.0001$ \\
& $3(\mathrm{n}=52)$ & $27(51.9)$ & 9.3 & $4.6-19.1$ & $<0.0001$ \\
Partial $^{* * *}$ & $0(\mathrm{n}=201)$ & $20(9.9)$ & 1.0 & - & - \\
& $1-2(\mathrm{n}=41)$ & $13(31.7)$ & 4.2 & $1.8-9.4$ & 0.0005 \\
Total $^{+}$ & $3(\mathrm{n}=52)$ & $23(44.2)$ & 7.2 & $3.5-14.9$ & $<0.0001$ \\
& $0(\mathrm{n}=179)$ & $1(0.6)$ & 1.0 & - & - \\
& $1-2(\mathrm{n}=38)$ & $2(5.3)$ & 9.9 & $0.9-216.0$ & 0.064 \\
& $3(\mathrm{n}=44)$ & $4(9.1)$ & 17.8 & $2.5-353.0$ & 0.011
\end{tabular}

$\overline{\text { *Score of tail lesions. } 0}=$ without lesion, normal tail; 1 = light lesion, with superficial loss of epithelium; 2 = moderate lesion with up to $50 \%$ of the tail injured; $3=$ severe lesion, with more than $50 \%$ injured or total loss of the tail.

** Ten pigs that lost their identification tag and eight pigs that died in the farms are not included in these analyses.

${ }^{* * *}$ Partial condemnations corresponded to processed meat, sausage and non-exportable meat whereas total condemnation corresponded to rendering meat.

+ Data concerning Farm 2 are not included in this analysis because no pigs showed total condemnation in this farm.

\section{DISCUSSION}

Observed field prevalence values are higher than prevalence previously reported in studies performed at abattoir (Hunter et al. 1999, Hunter et al. 2001). Carcasses of animals without evidence of tail-biting at slaughter may be condemned, as it was observed in the present study, and inspection services may not associate it with tail-biting. Collectively, these observations show that tail-biting prevalence values found in slaughterhouses are probably underestimating field prevalence.

Depending on the age of pigs when lesions occur, tail injuries may have already healed at the time of slaughter, as it was observed in the present study. This favorable evolution suggests that the applied control measures such as the treatment of animals were adequate to promote healing of the tail lesion. In addition, the fact that tail-biting was diagnosed relatively early, i.e., 70 to 95 days before slaughter may have contributed to the almost complete disappearance of active lesions when pigs were sent to slaughter.

The higher condemnation rate of carcasses with tail biting lesions was also observed in a previous study (Kritas \& Morrison 2007). The fact that risk of carcass condemnation increased with the severity of tail lesion is in agreement with results of other studies (Braga et al. 2006, Walker \& Bilkei 2006). According to SIF norms (Brasil 1995), non-exportation, preserve, sausage and rendering correspond to $23 \%, 35 \%, 57 \%$ and $99 \%$ of economic loss in carcass value, respectively. Among 93 animals (Table 4) with tail lesions, the carcasses of 29, 5, 2 and 6 pigs were routed for non-exportable, preserve, sausage and rendering categories, respectively. By multiplying the number of carcasses by the correspondent estimated loss, this represented a loss of 15.5 carcasses among the 93 animals with tail-biting lesions diagnosed in the field. In other words, to every 5 pigs diagnosed with cannibalism in the finishing unit, there would be a loss of about 0.8 carcass.

The negative impact of the higher tail lesion severity on ADWG observed in two of the four evaluated farms, confirms the observation of Wallgren \& Lindahl (1996) that weight gain was $25 \%$ lower in severely bitten animals than in pigs without tail lesions. In another study, severely bitten animals presented narrower thoracic circumference than those with mild or no tail lesions (Kritas \& Morrison 2004). Even in outdoor production, severely bitten pigs were significantly lighter at slaughter than those not bitten (Walker \& Bilkei 2006). During the course of infectious diseases, inflammatory processes may reduce daily weight gain and feed efficiency (Van Heutgen et al. 1994). Inflammatory cytokines secreted by myeloid cells in sick animals may directly affect weight gain, but may also indirectly influence it by reducing voluntary feed intake. In addition, several other physiological alterations may reduce weight gain, such as increased catabolic hormone secretion (e.g., glucocorticoids), gluconeogenesis, liver synthesis of acute phase proteins and nitrogen excretion, as well as inhibited anabolic hormone synthesis by the adenohypophysis (Kelley et al. 1993, Webel et al. 1997). In pigs suffering cannibalism, Heinonen et al. (2010) found higher levels of acute phase proteins, as compared to animals with no lesions, suggesting that the systemic dissemination of bacteria and/or bacterial toxins probably results in higher production of inflammatory mediators and in stronger systemic response than a single, localized tissue lesion. Weight gain reduction in pigs affected by tail biting may be explained by factors such as discomfort caused by the lesions, stress, occurrence of secondary infections and possibly lower feed intake. It was not possible to measure feed intake during the experimental period, preventing the determination of a possible relation between tail biting and feed conversion. Even though slaughter weight may not be always compromised, this does not mean that there will be no economic 
losses, as these may be related to mortality, drug usage, and increased labor, in addition to the evident losses by higher carcass condemnation.

Cannibalism caused the death or sacrifice of a few animals during the finishing period. However, it was representative, because $75 \%$ (6/8) of the pigs that died had tail biting lesions, which is in agreement with the study of Kritas \& Morrison (2004), where 60 to $70 \%$ of the pigs that died during a cannibalism outbreak had tail lesions. In addition to growth depression, mortality also account for economic losses during a cannibalism outbreak. Furthermore, because all dead CAN pigs had been previously medicated, the additional cost of this medication must also be taken into account.

At slaughter, the high number of lesions in carcasses of bitten animals and the significant association between tail lesions and the presence of pleuritis and abscesses, irrespective of the severity of tail lesions, is in agreement with findings of Kritas \& Morrison (2007). The higher occurrence of abscesses in the vertebral column (48.6\%) corroborates results of Huey (1996). The main agents isolated from the abscesses (Streptococcus spp. and Arcanobacterium pyogenes) were also the most frequently isolated microorganisms in other studies (Huey 1996, Martinez et al. 2007). The presence of Pasteurella multocida in $8.7 \%$ of the lung lesions was probably not related to tail biting, as this agent colonizes the respiratory tract by aerogenic route, as opposed to Streptococcus spp. and Arcanobacterium spp., which may penetrate the body through tail lesions and systemically spread by the hematogenous route. According to Huey (1996), the evolution of abscesses in the vertebral column can take several weeks or even months, while the original lesions have already healed at slaughter time, explaining the presence of abscesses with no active lesions in the external surface of the tail.

An injured tail is an important site of entrance for different bacteria causing secondary infections, and microorganisms spread through lymph vessels (Dyce et al. 2010), cerebrospinal fluid (Huey 1996) and mainly by the hematogenous route (Getty \& Ghoshal 1967). The abundant blood supply of the tail allows easy access of bacteria to the collateral cutaneous vein, which enters the vertebral canal between the second and third sacral vertebra (Getty \& Ghoshal 1967), explaining the frequent finding of abscesses in the vertebral column. Bacteria can be carried to other organs by the blood stream, which may explain the fact that animals with severe tail lesions presented higher odds of presenting arthritis than those without tail lesions, corroborating other studies (Martinez et al. 2007). Due to its abundance of small capillaries, the lung is one of the most easily affected organs, explaining the observed embolic bacterial pneumonia, pleuritis and lung abscesses. This may indicate that the antimicrobial treatments used and the control measures taken did not always prevent bacterial dissemination from the initial tail lesion foci. The severe tissue loss and necrosis in these areas and their considerable fecal contamination due to the small distance from the rectum, could explain why complications in this kind of infection are so frequent.

\section{CONCLUSIONS}

Clinical evolution of tail biting lesions was favorable, and most animals showed healed lesions at slaughter. Nevertheless, tail biting was associated with increased carcass condemnation. Carcass condemnation in pigs with healed tail lesions stresses the importance of including field diagnosis followed by carcass inspection in studies designed to assess this condition.

In addition to an increased mortality rate, tail biting was associated with locomotion disorders and with the presence of abscesses at vertebral column, inguinal area and lungs.

Tail biting was associated with a lower weight gain in two of the four evaluated farms.

Acknowledgements.- This study was supported with research grants by the National Council of Technological and Scientific Development (CNPq, Proc. 578376/2008-3)

\section{REFERENCES}

Barrow G.I. \& Feltham R.K.A. 1999. Cowan and Steel's Manual for the Identification of Medical Bacteria. $3^{\text {rd }}$ ed. Cambridge University Press, Cambridge. 331p.

Braga D.P., Del'arco A.E. \& Dias R.C. 2006. Condenação de carcaças suínas por caudofagia em frigorífico sob Inspeção Federal no município de Concórdia, Santa Catarina. Acta Sci. Vet. 34:319-323.

Brasil 1995. Departamento de Inspeção de Produtos de Origem Animal, Ministério da Agricultura, Pecuária e Abastecimento. Available at $<\mathrm{http}$ ://www.agricultura.gov.br> Accessed on Dec. 20, 2010.

Breuer K., Sutcliffe M.E.M., Mercer J.T., Rance K.A., O'Connell N.E. \& Sneddon I.A. 2005. Heritability of clinical tail-biting and its relation to performance traits. Livest. Prod. Sci. 93:87-94.

Dyce K.M., Sack W.O. \& Wensing C.J.G. 2010. The vertebral column, back, and thorax of the pig, p.762-764. In: ibid. (Eds), Textbook of Veterinary Anatomy. Saunders Elsevier, Missouri.

Getty R. \& Ghoshal N.G. 1967. Applied anatomy of the sacrococcygeal region of the pig as related to tail bleeding. Vet. Med. Small Anim. Clin. 62:361-367.

Heinonen M., Orro T., Kokkonen T., Munsterhjelm C., Peltoniemi C. \& Valros A. 2010. Tail biting induces a strong acute phase response and tail-end inflammation in finishing pigs. Vet. J. 184:303-307.

Huey R.J. 1996. Incidence, location and interrelationships between the sites of abscesses recorded in pigs at a bacon factory in Northern Ireland. Vet. Rec. 138:511-514.

Hunter E.J., Jones T.A., Guise H.J., Penny R.H. \& Hoste S. 1999. Tail biting in pigs: The prevalence at six UK abattoirs and the relationship of tail biting with docking, sex and other carcass damage. Pig Journal 43:18-32.

Hunter E.J., Jones T.A., Guise H.J., Penny R.H.C. \& Hoste S. 2001. The relationship between tail biting in pigs, docking procedure and other management practices. Vet. Journal 161:72-79.

Kelley K.C., Kent S. \& Dantzer R. 1993. Why sick animals don't grow: An immunological explanation, p.119-132. In: Hollis G.R. (Ed.), Growth of the Pig. CAB International, Wallingford.

Kritas S.K. \& Morrison R.B. 2004. An observational study on tail biting in commercial grower-finisher barns. J. Swine Health Prod. 12:17-22.

Kritas S.K. \& Morrison R.B. 2007. Relationships between tail biting in pigs and disease lesions and condemnations at slaughter. Vet. Rec. 60:149-152.

Martínez J., Jaro P.J., Aduriz G., Gómez E.A., Peris B. \& Corpa J.M. 2007. Carcass condemnation causes of growth retarded pigs at slaughter. Vet. J. 174:160-164.

Moinard C., Mendl M., Nicol C.J. \& Green L.E. 2003. A case control study of on-farm risk factors for tail biting in pigs. Appl. Anim. Behav. Sci. 81:333355 . 
SAS 2005. Statistical Analysis Systems, Institute Inc. 9.1.3. SAS/STAT User's Guide, SAS. Institute Inc, Cary.

Schulze W. 1980. Klinische Untersuchungen, p.3-32. In: Schulze W., Bichhardt K., Bollwahn W., Michwitz G.V. \& Plonait H. (Eds), Klinik der Schweinekrankheiten. M. und H. Schaper, Hannover.

Sobestiansky J. \& Barcellos D.E.S.N. 2007. Monitoramentos clínicos, p.723726. In: Ibid. (Eds), Doenças dos Suínos. Cânone Editora, Goiânia.

Sobestiansky J., Barcellos D.E.S.N., Driemeier D. \& Matos M.P.C. 2007. Monitoramento de abate, p.743-764. In: Sobestiansky J. \& Barcellos D.E.S.N. (Eds), Doenças dos Suínos. Cânone Editora, Goiânia.
Van Heutgen E., Spears J.W. \& Coffet M.T. 1994. The effect of dietary protein on performance and immune response in weanling pigs subjected to an inflammatory challenge. J. Anim. Sci. 72:2661-2669.

Walker P.K. \& Bilkei G. 2006. Tail-biting in outdoor pig production. Vet. Journal 171:367-369.

Wallgren P. \& Lindahl E. 1996. The influence of tail biting on performance of fattening pigs. Acta Vet. Scand. 37:453-460.

Webel D.M., Finck B.N., Baker D.H. \& Johnson R.W. 1997. Time course of increased plasma cytokines, cortisol and urea nitrogen in pigs following intraperitoneal injection of lipopolysaccharidae. J. Anim. Sci. 75:1514-1520. 